Multidisciplinary

SCIENTIFIC JOURNAL OF

MARITIME RESEARCH

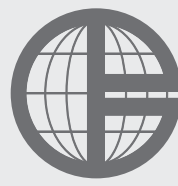

University of Rijeka

Faculty of Maritime

Studies Rijeka
Multidisciplinarni

znanstveni časopis

POMORSTVO

\title{
Comparative Analysis of the Related Interests of Relevant Stakeholders in the Development of Seaports in Relation to the Spatial Concept of the City
}

\author{
Donald Schiozzi ${ }^{1}$, Alen Jugović ${ }^{2}$, Željko Smojver ${ }^{3}$ \\ ${ }^{1}$ Port Authority Rovinj, Coast/Waterfront Aldo Rismondo 2, 52210 Rovinj, Croatia, e-mail: donald@port-rovinj.hr \\ ${ }^{2}$ University of Rijeka, Faculty of Maritime Studies, Studentska 2, 51000 Rijeka, Croatia, e-mail: ajugovic@pfri.hr \\ ${ }^{3}$ Rijeka Plus d.o.o., Školjić 15, 51000 Rijeka, Croatia, e-mail: zeljko.smojver@rijeka-plus.hr
}

\section{ABSTRACT}

The seaport, as a link of the transport chain, is oriented towards the development of the maritime system of the country and the summit place of traffic slope from all transport routes and means of transport. While the city, as a community of residents, is oriented towards promoting the well-being of citizens and the quality of their lives, so it strives to ecological, cultural and visual values. This relation of interest is merely one of the numerous relations of interest of the relevant stakeholders in the planning and development of the seeports in relation to the spatial concept of cities deriving from a constrained coexistence in a restricted area - as two separate entities whose interests and objectives appear to be different at first sight. In this paper, the relations of interest of the relevant stakeholders have been analyzed, quantitative and qualitative variables have been evaluated that influence the development of the seaports in relation to the spatial concept of the city. The research has highlighted the need to look at and analyze all relevant stakeholders interests, of which the most important are: state - local community, state - managing body of the port, state - economy, local community managing body of the port, local community - economy and economy - managing body of the port.
\end{abstract}

\section{ARTICLE INFO}

Preliminary communication

Received 20 April 2018

Accepted 14 May 2018

Key words:

Harbour

Harbour area

Local community

Development plans

Stakeholders

Managing body of the port

\section{Introduction}

The port is, as a port system, a particularly important segment of the valuation of the sea and the maritime orientation of the country and, together with shipping and shipbuilding, is a fundamental link in the maritime economy [1, 12]. The operation of the seaport has been determined by a number of factors with regard to the complex function of the port in the traffic and economic system, as well as its position that is the most commonly in the city centre. It is in the fact that most coastal cities have developed along or around the port, or the seaport, and port areas have become an indispensable part of the cities, so there are certain conflicts in their development. This applies in particular to smaller seaports, i.e. ports of the county (regional) and local importance. The aforementioned contrast between cities and ports arises most often from constrained coexistence in a restricted area - as two separate entities whose interests and goals at first look differently.

Faster social, economic and cultural changes at a global and national level are particularly evident in the develop- ment of the port and city space [9]. By building a port, roads, expanding settlements and shrinking the coast, the surface of the built and landscaped area (port) increases unfortunately at the cost of the natural one, which is also a threat to sustainable development. Given the fact that the coast is (basic) natural resource of the ensuring sustainable development of the port, there is a growing need for quality programmes using the coastal area and the regulation of relations in the area which represent an answer to the rapidly increasing population, industrialization and urbanization $[1,6]$.

Effective linking of stakeholders with the relation of interest is one of the key factors for competitiveness of the state, region and city. Namely, high-quality relations between stakeholders create the conditions for achieving development projects, attracting entrepreneurs and investors, and thus increasing the quality of life (new working places, better standard, more valued offerings, more developed infrastructure, healthier and more beautiful environment), increased demand, attracting visitor and younger and more educated citizens, who are the fundamental development resource of the modern economy. 


\section{Important Stakeholders in the Seaports Development in Relation to the Spatial Concept of the City}

The successful and rational development of the county and local ports in relation to the spatial concept of the city requires a perspective, determination and proper valuation of all the elements that directly or indirectly influence their functioning. The synergistic effect of these elements and the harmonious formation and/or development of the county and local ports will result in numerous positive effects, among which the most significant are: increasing the traffic of passengers and cargo in the port, increasing the number of tourists, employments of the new manpower, creating new income, immigration of the population and other elements [3], as well as in various sections of the development of the county and local ports such as: state, economy, local community and the managing body of the port.

The stakeholders are connected with the relations of interest, as shown in Figure 1.

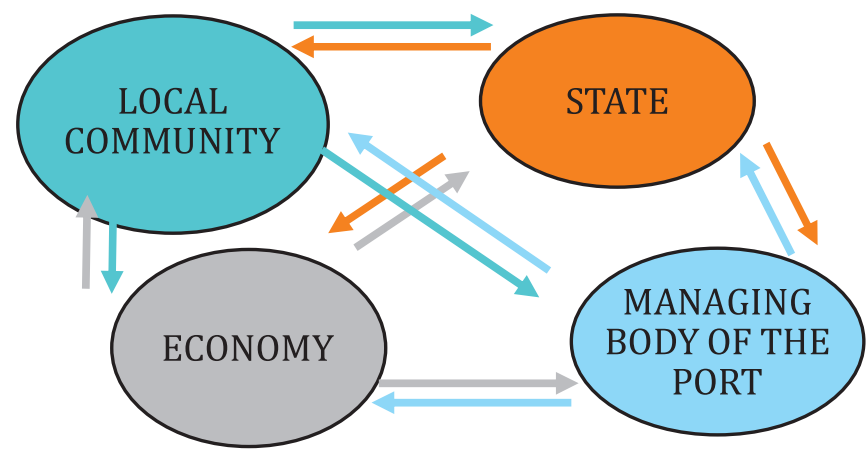

Figure 1 Stakeholders in the Development of the County and Local Ports and their Relation of Interest

\section{Analysis of the Relation of Interest Between Stakeholders}

In order to best describe and analyze the mentioned relations of interest between stakeholders, a correlation analysis has been used, i.e. the methodology of qualitative and quantitative variables [5]. The most important variables are:

- GNP (gross national product) - gross national product index of the local community [8];

- Contributions - the financial value of the paid contributions of the local community;

- Construction and maintenance of the port infrastructure - the financial value of the investment body of the port management in the design, construction and maintenance of the port infra and superstructure;

- Economic moorings - number of economical moorings;

- Investment policy in the maritime domain - the financial value of investment in the maritime domain;

- Local community investment policy - the financial value of a local community investment in designing, planning and maintaining a maritime domain or port area;
- Investments in maintaining the environmental protection - the financial value of the investment of the economic sector in maintaining the environmental protection;

- Communal moorings - number of communal moorings [4];

- Nautical moorings - number of nautical moorings [4];

- Tax - the financial value of the local community tax paid;

- Surface of the port area - the ratio of the surface of the port and the city area [2];

- The needs of the local population for regular users - the required number of communal, economic, fishing and nautical moorings [8];

- Fees and dues - the financial value of the revenue, fees and dues of the port managing body;

- Workplaces - number of workplaces;

- Manpower - number of unemployed persons;

- Development strategy - the financial value of projects and the amount of subsidies that the state provides for the development of the port;

- Costs - the financial value of costs, i.e. expenses of the port fees and dues to the managing body of the port;

- Economic development - quality and speed of economic development [11];

- Cultural value - assessment of cultural component evaluation;

- Monitoring - assessment the effectiveness of state monitoring in the implementation of adopted legal acts and various regulations;

- Tax policy - assessment of the efficiency of the tax policy;

- Legal framework - quality assessment of the legal system, speed of adoption and amendments of legal acts;

- Spatial plans - quality assessment of spatial distribution when adopting spatial plans;

- Order in port - quality assessment of order in the port;

- Security standards - the quality assessment of legal acts that consider the security standards that the state imposes through the competent ministry and are directly related to maritime traffic, i.e. the managing body of the port [7];

- Level of security in the port area - port safety assessment [7];

- Level of environmental protection - assessment of the environmental protection level;

- Market - assessment of the economic sector's satisfaction with the market;

- Satisfaction of the economic sector - assessment of the economic sector's satisfaction with the state economic policy [10];

- Satisfaction of the local population - assessment of the satisfaction of the local population as regular port service users with the spatial plan (i.e. the spatial concept of the city). 


\section{State - Local Community}

The relation of interest between the state and the local community can be described by specific indicators and variables where the output indicators of one stakeholder are also input indicators for the other.

Quantitative variables for the relation of interest between the state and the local community refer to (Figure 2): development strategy, taxes and contributes.

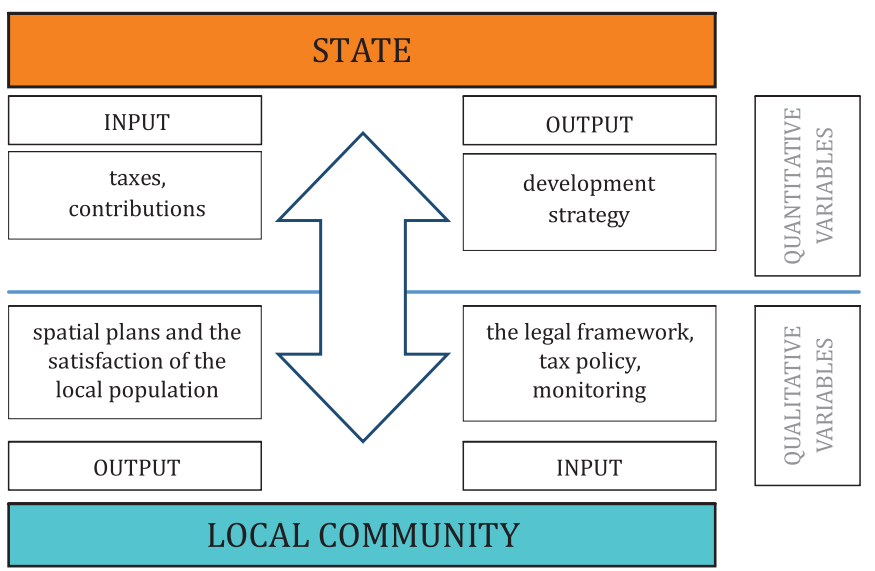

Figure 2 The Relation of Interest between the State and the Local Community

Qualitative variables for the relation of interest between the state and the local community refer to: the legal framework, tax policy, monitoring, spatial plans and the satisfaction of the local population.

In conclusion, it can be established that the relation of interest between the state and the local community is most represented in the financial indicators and the assessment of the efficiency of the entire system.

\section{State - the Managing Body of the Port}

The relation of interest between the state and the managing body of the port may be displayed and measured by the analysis of quantitative and qualitative variables.

Quantitative variables for the relation of interest between the state and the managing body of the port (Figure 3) refer to: development strategy, tax, contributions, construction and maintenance of port infrastructure and investment policy in the maritime domain.

Qualitative variables for the relation of interest between the state and the managing body of the port refer to: legal framework, regulations, level of the safety of the port area, security standards and monitoring.

Based on the aforesaid, it is evident that the relation of interest between the state and the managing body of the port is dominated by quantitative variables, i.e. financial indicators of investment in the design, construction and maintenance of the complete port system.

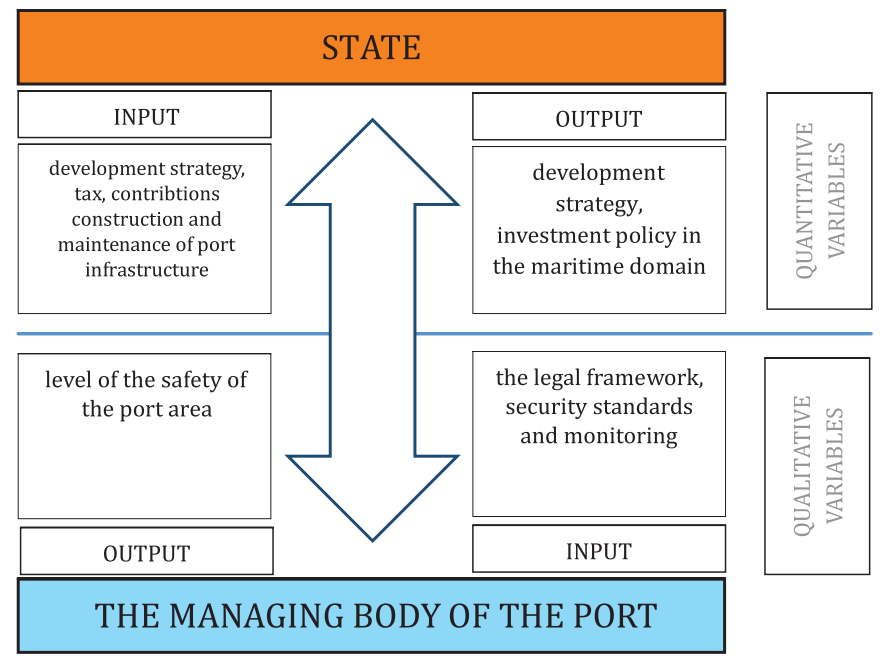

Figure 3 The relation of Interest between the State and the Managing Body of the Port

\section{State - Economy}

The relation of interest between the state and the economy can be presented and measured by the analysis of quantitative and qualitative variables.

Quantitative variables for the relation of interest between the state and the economy refer to (Figure 4): tax, contributions, GNP and security standards.

Qualitative variables for the relation of interest between the state and the economy refer to: economic development, level of satisfaction of the economic sector, legal framework and monitoring.

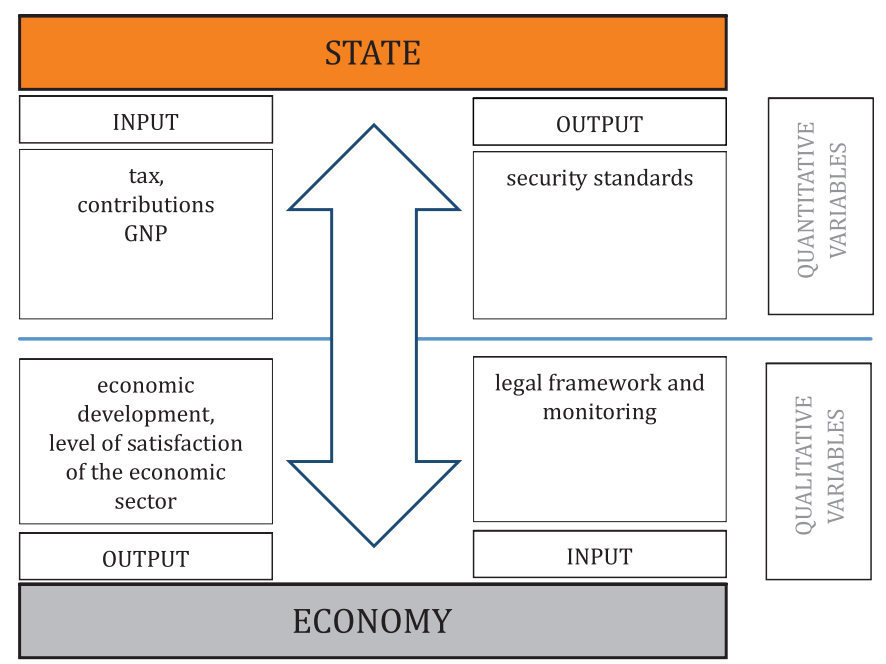

Figure 4 The Relation of Interest between the State and the Economy

The relation of interest between the state and the economy is confirmed by overcoming the outgoing quantitative variables of the economy, i.e. the financial indicators of paid taxes, contributions and the GNP index. 


\section{Local Community - the Managing Body of the Port}

The relation of interest between the local community and the managing body of the port may be displayed and measured by the analysis of quantitative and qualitative variables.

Quantitative variables for the relation of interest between the local community and the managing body of the port refer to (Figure 5): surface of the port area, users' needs, local unit investment policy, fees and dues, communal moorings, workplaces, investments in maintaining the environmental protection.

Qualitative variables for the relation of interest between the local community and the managing body of the port refer to: the level of satisfaction of the economic sector, the level of satisfaction of the local population - the users of services, the level of satisfaction of the yachtsmen, the level of environmental protection, the level of security of the port infrastructure and the cultural value.

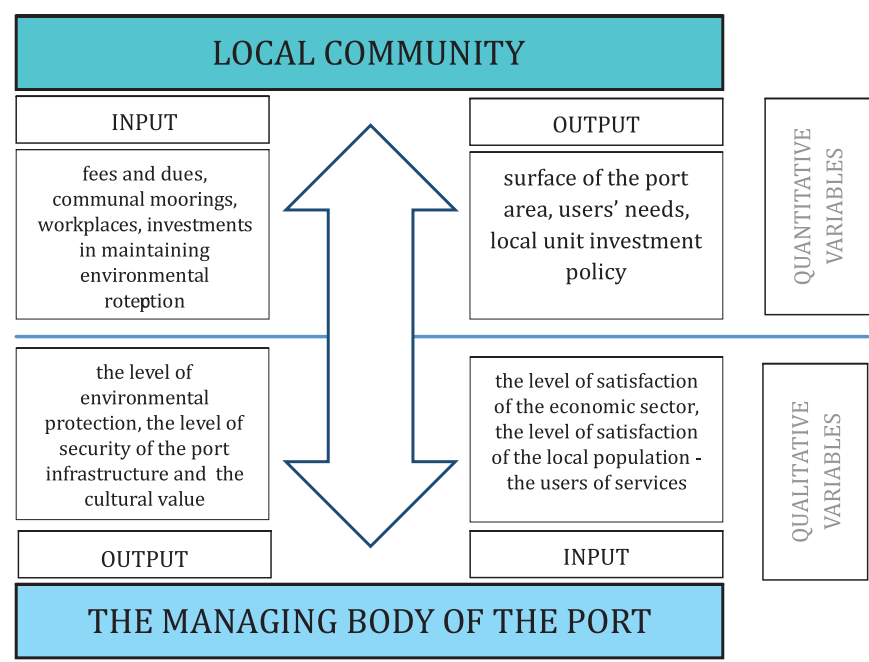

Figure 5 The Relation of Interest between the Local Community and the Managing Body of the Port

The relation of interest between the local community and the managing body of the port is far more complex and demanding for both stakeholders, since the main hypothesis is based on the development of the county and local ports in relation to the city component and thus this relation of interest can be the basis for defining indicators, the value of the measurement units.

\section{Local Community - Economy}

The relation of interest between the local community and the economy can be displayed and measured by the analysis of quantitative and qualitative variables.

Quantitative variables for the relation of interest between the local community and the economy refer to (Figure 6): manpower, workplaces, contributions, taxes and investments in maintaining environmental protection.
Qualitative variables for the relation of interest between the local community and the economy refer to: market, cultural value, environmental protection and the satisfaction of the local population.

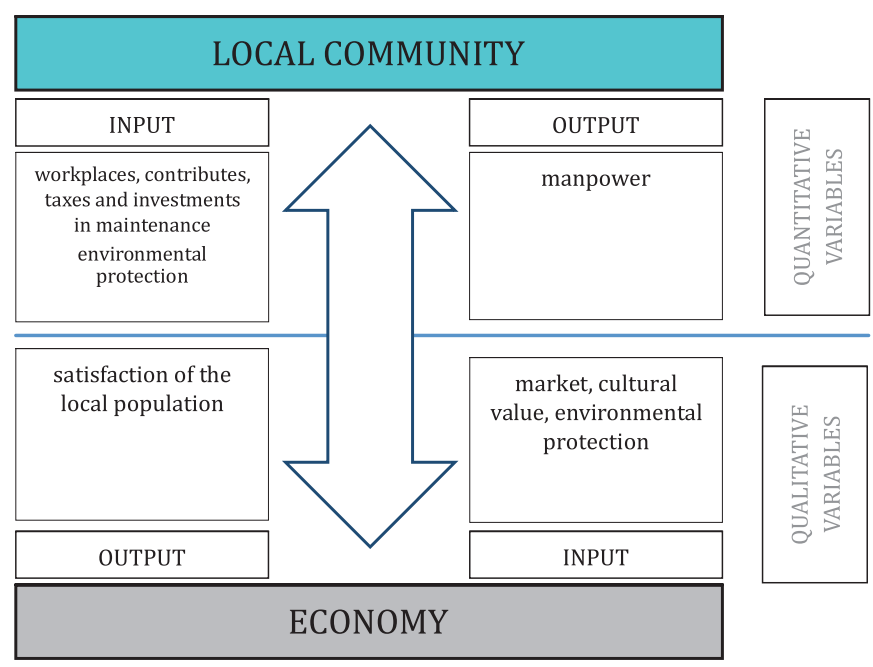

Figure 6 The Relation of Interest between the Local Community and the Economy

Based on the aforesaid, it is apparent that in the relation of interest between the local community and the economy prevail the input quantitative variables of the economy, i.e. the need for the manpower (workplaces offer), contribution payment, various taxes and investments in maintaining environmental protection.

\section{Economy - the Managing Body of the Port}

The relation of interest between the economy and the managing body of the port may be presented and measured by the analysis of quantitative and qualitative variables.

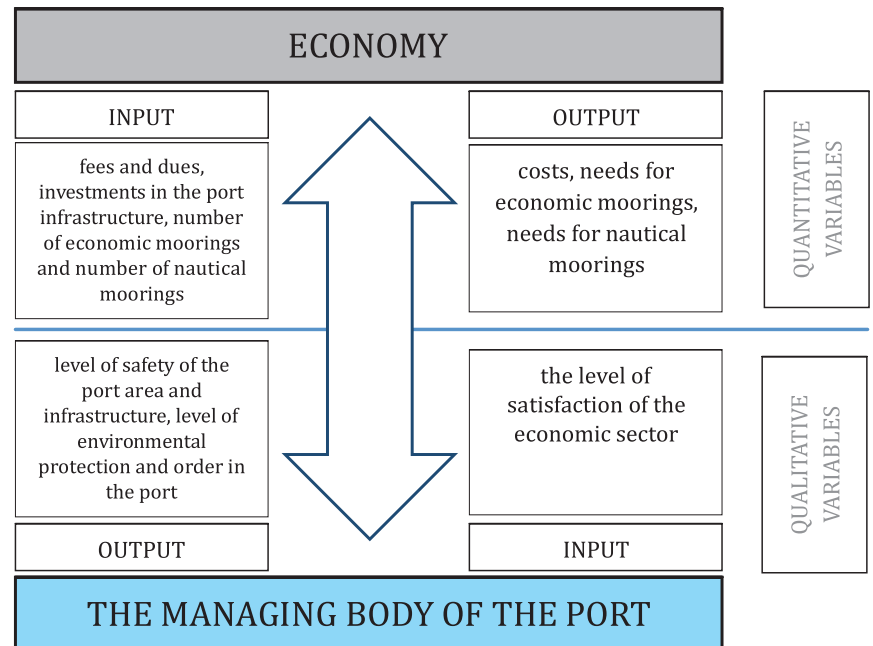

Figure 7 The Relation of Interest between the Local Community and the Economy 
Quantitative variables for the relation of interest between the economy and the managing body of the port refer to (Figure 7): costs, needs for economic moorings, needs for nautical moorings, fees and dues, investments in port infrastructure, number of economic moorings and number of nautical moorings.

Qualitative variables for the relation of interest between the economy and the managing body of the port refer to: the level of satisfaction of the economic sector, level of safety of the port area and infrastructure, level of environmental protection and order in the port.

In conclusion, it is clear that the relation of interest between the economy and the managing body of the port is dominated by output variables of the managing body of the port, or income from port dues and fees, the number of offered economic and nautical moorings, level of safety of the port area and the environmental protection.

\section{Conclusion}

The port, as a link of the transport chain, is oriented to cost effectiveness, productivity, market competition and business development, and, in the end, to satisfying the needs of the local population. While the city, as a community of residents, is oriented towards promoting the wellbeing of citizens and the quality of their lives, and thus tends to ecological, cultural and visual values. This distortion of vision contributes to the conflict that makes the physical and functional compatibility of these two centres questionable.

The problems mentioned are also visible in the Republic of Croatia, where all the relevant factors affecting the development of the city and the port as a common system are practically not taken into account, which has the consequence that port and city problems are often considered separately. As the most significant problem in the development of the ports of the county and the local importance of their port areas is that the plans for the development of the county and the local ports that port administrations provide as the managing body of the port and the port area do not usually have coverage in the spatial-planning solutions of cities and counties. A reverse situation also appears, when the port authority with the city and/or county planning solutions related to the port are acquainted only through the opinion of the competent administrative body for the implementation of the spatial planning documents, and it is then too late for significant changes or interventions. The aforesaid facts have indicated that all subjects have not been active stakeholders in the planning of the ports and associated port areas in the spatial planning documents. The result of such a situation are the port areas that are not based on the development plans of the managing body of the port and which often do not meet the requirements of the port activities or capacities structures, and, in particular, do not meet the requirements of the surface and shape of the port area.
The results of the researche have indicated that it is necessary to simplify the process and procedure for the adoption of spatial plans for the development of the county and local ports, shortening time and space, eliminating empty and backward steps, greater specialization, harmonization of legal definitions, more efficient use of information and more generous application of science and knowledge, rational development of the county or local port in relation to the complement of the spatial conception of the city.

A more detailed analysis and review of the relevant legislation regulating spatial and urban planning, spatial planning and status of the port area in the Republic of Croatia has shown more disadvantages than advantages of the existing spatial planning of ports and port areas. The current way of planning ports and port areas is diverse and questionable.

Taking into account these deficiencies and considering the county and local ports as part of the overall port system of a single state that, in order to properly and successfully function and achieve the set goals, must strive for the connections of all its subsystems and elements. To conclude with, it can be pointed out that the current way of planning the development of the county and local ports are not a satisfactory one. In order to overcome these problems and disadvantages of planning the development of the county and local ports, the paper has pointed out and defined the role and interdependence of all stakeholders, and the widespread support of the local community or the "local" city as well.

\section{References}

[1] Babić, M.: Prostorno planiranje - Temeljni čimbenik dugoročnog održivog razvoja grada, Rijeka, Zbornik radova: Zavod za prostorno uređenje Primorsko-goranske županije (2015), pp. 273-280.

[2] Hoyle, B.: Global and local change on the Port-city waterfront, American Geographical Society, Geographical Review, Vol. 90, No. 3 (Jul., 2000), pp. 395-417.

[3] Jugović, A.: Model racionalnog upravljanja pomorskoputničkim lukama Republike Hrvatske, Ekonomska misao i praksa, Časopis Sveučilišta u Dubrovniku, Dubrovnik, XVII, 2008 [1] Kesić, B.: Organizacija i ekonomika lučkih sistema, Fakultet za pomorstvo i saobraćaj, Rijeka, 1992.

[4] Kolanović, I.: Temeljne dimenzije kvalitete lučke usluge, Pomorstvo, Journal of maritime Studies, Pomorski fakultet Sveučilišta u Rijeci, Rijeka, 2008, p. 45.

[5] Macharis, C., Turcksin, l., Lebeau, K.: Multi actor multi criteria analysis (MAMCA) as a tool to support sustainable decisions: State of use, Vrije Universiteit, Brussel, Decision Support Systems 54 (2012), pp. 610-620.

[6] Mastelić Ivić, S. et al.: Organizacija prostornih resursa, Simpozij o inženjerskoj geodeziji / SIG2007.

[7] Milošević Pujo, B., Radovan, H.: Sprečavanje onečišćenja mora po MARPOL - konvenciji, Naše more 52(5-6), 2005, pp. 231-234.

[8] Perišić, A., Wagner, V.: Indeks razvijenosti: Analiza temeljnog instrumenta Hrvatske regionalne politike, Institut za javne financije, Zagreb, 30/15, 2014. 
[9] Prostorno planiranje u Primorsko-goranskoj županiji, Javna ustanova Zavod za prostorno uređenje Primorsko-goranske županije, 2011.

[10] Rudan, E.: Uloga lokalnog stanovištva u razvoju turizma destinacije, pregledni rad, Tranzicija, Vol. 14, No. 29, 09. 2012, pp. 58-67.
[11] Vidučić, Lj., Vidučić, V.: Uloga prometa i morskoga putničkog brodarstva u razvitku hrvatskog turizma, Suvremeni promet, Hrvatsko znanstveno društvo za promet, 22, Zagreb, 2004, 1-2.

[12] Vilke, S.: Značenje tržišnog pristupa za razvitak luke, Pomorski zbornik 41(2003) I, pp. 337-359. 